\title{
THE STUDENTS' FAMILIARITY TOWARD ENGLISH PHRASAL VERBS: A CORPUS-BASED STUDY
}

\author{
Andi Rizki Fauzi \\ STIPARY Tourism Academy \\ Jl. Ring Road Utara No.4, Nanggulan, Maguwoharjo, Kec. Depok, Kabupaten Sleman, Daerah Istimewa \\ Yogyakarta 55282 \\ fuaziandirizki2@gmail.com
}

\begin{abstract}
A phrasal verb is considered a challenging area for foreign language learners including those who learn English for specific purposes e.g English for tourism. However, to gain a good level of English, the students must learn phrasal verbs as they are commonly used by native English speakers. This study aimed to know the phrasal verb found in English for Tour and Travel Corpus (ETTC) and whether the students are familiar with the phrasal verbs found by differentiating them with prepositional verbs. The students' familiarity was measured through a questionnaire and their ability to use them in speaking. ETTC was built from 100 articles related to Tour and Travel, and the annotation using CLAWS 7 was conducted to identify the phrasal verb found in the corpus. Then, the phrasal verbs were listed based on the lemma. Based on the result of the analysis, there are 172 multi-word verbs classified as phrasal verbs. The students who were expected to have already been familiar with them were not able to differentiate between phrasal verbs and prepositional verbs. More interestingly, they do not know all the meaning of phrasal verbs found in ETTC and the speaking test result also proved that using phrasal verbs still needed more effort as the students could not use them accurately. The result of this research can be preliminary data for further research, particularly in teaching and learning English for a specific purpose.
\end{abstract}

Keywords: Corpus, English Phrasal Verbs, English for Specific Purpose, Familiarity, and Prepositional Verbs

\begin{abstract}
Abstrak
Verba frasal dianggap sebagai area yang sulit bagi pelajar bahasa asing termasuk mereka yang belajar Bahasa Inggris untuk tujuan khusus, misalnya Bahasa Inggris untuk pariwisata. Namun, untuk memiliki kemampuan Bahasa Inggris yang baik, mahasiswa harus mempelajari verba frasal mengingat verba frasal biasa digunakan oleh penutur asli bahasa Inggris. Penelitian ini bertujuan untuk mengetahui verba frasal yang ditemukan di English for Tour and Travel Corpus (ETTC) dan mengetahui apakah mahasiswa akrab dengan verba frasal tersebut dengan cara membedakan antara verba frasal dan kata kerja preposisi. Tingkat keakraban terhadap verba frasal diukur menggunakan kuisioner dan kemampuan mereka dalam menggunakannya dalam tes berbicara. ETTC dibuat dari 100 artikel yang berhubungan dengan tour and travel dan anotasi menggunakan CLAWS 7 dilakukan untuk mengidentifikasi verba frasal yang terdapat dalam korpus. Kemudian, verba frasal didaftar berdasarkan lemma. Berdasarkan hasil analisa data, terdapat 172 kata kerja multi-kata yang diklasifikasikan sebagai verba frasal. Mahasiswa yang diharapkan sudah akrab dengan verba frasal ternyata tidak mampu membedakan antara verba frasal dan kata kerja preposisi. Menariknya lagi, mereka tidak mengetahui semua arti dari verba frasal yang digunakan dalam ETTC. Hasil tes berbicara juga membuktikan bahwa penggunaan phrasal verbs masih membutuhkan lebih banyak usaha karena mahasiswa tidak dapat menggunakannya secara akurat. Hasil penelitian ini dapat menjadi data awal untuk penelitian selanjutnya, khususnya dalam pembelajaran bahasa Inggris untuk tujuan khusus.
\end{abstract}

Kata kunci: Korpus, Verba Frasal, Bahasa Inggris untuk Tujuan Khusus, Keakraban, dan Kata Kerja Preposisi 


\section{Introduction}

Vocabulary is now becoming a concern for English learners and researchers since it plays a vital role in the use of languages. According to Alqahtani (2015), a limited secondlanguage vocabulary prevents effective communication. The knowledge of vocabulary can also be an indication of English learners' ability.

With the importance of vocabulary in the context of learning English as a foreign language, of course, vocabulary currently becomes the focus of language research. Zarifi \& Mukundan (2013) stated that the direction of considerable linguistic research is now being shifted from syntax and phonology to lexicons and multi-word expressions.

One of the multi-word expressions is phrasal verbs. According to McCarthy \& O'Dell (2004), "Phrasal verbs are verbs that consist of a verb and a particle". Particles here are adverbs and prepositions. Furthermore, according to Frank (2002), a phrasal verb is a new vocabulary item formed by combining a verb and a preposition. However, not all combinations of verbs and prepositions can be called phrasal verbs. Two examples below can show the difference of verb+ preposition in sentences.

1) I turn off the light

2) I turn to the right

The first sentence in the example above shows the use of the phrasal verb 'turn off", in which the phrase can be broken down into I turn the light off, whereas a prepositional verb cannot be separated e.g. I turn the right to.
In the learning of English, phrasal verb use cannot be avoided because English speakers use it often in daily communication. Phrasal verbs are phrases, which are often utilized by native speakers and are needed to be fluently spoken in English (Garnier \& Schmitt, 2014). However, the phrasal verb has multiple meanings. As exemplified by Garnier, \& Schmitt (2014) that the phrase "go on" has 22 meaning sense entries in the Collins COBUILD Phrasal Verbs Dictionary. As a result, learners may be quickly overwhelmed by the amount of information included inside a single entry.

Due to their idiomatism, polysemic nature, and significance variance, PVs constitute one of the most difficult fields of foreign language learning. Four reasons why PVs have been considered one of the most notorious difficult features in the English language were also cited in Sonbul, et. all (2020) such as (1) there is an overwhelming number of PVs in English. (2) PVs, including English, are the unique feature of specific languages. (3) PV is a composite of a semantically treated unit of two or more orthographic words. (4)PVs in nature are highly polysemic and have multiple meanings in a large number of PVs.

Thim (2012) divided phrasal verb into three semantic types namely 'literal', 'aspectual' and 'non-compositional (or 'idiomatic'). Idiomatic constructions are different from the two preceding groups in that their meaning cannot be inferred from the meaning of their elements. He gives examples as follows:

1) My husband actually said to me that giving up smoking was easy 
because he's done it plenty of times.

2) He could not make it out, nor could he trust his own memory

From the examples above, the meaning of the phrase "giving up" and "make out" are not transparent. Therefore, from the types of the phrasal verb above, idiomatic phrasal verbs are certainly the type that has attracted the most attention in the teaching of English as a foreign language (Thim, 2012). However, Tanihardjo (2019) found that literal and idiomatic PVs (idiomatic phrasal verbs) for EFL learners are equally complicated.

Based on the explanation above, the use of phrasal verbs is avoided as the idiomatic meaning that cannot be guessed from the construction of phrasal verbs. This makes English learners prefer to use one basic word, although according to Bradwell (2006) the use of phrasal verbs makes learners sound more natural when speaking English. Blau, Gonzales, and Green (1983) partitioned students' issues with PVs into two classifications: semantic or vocabulary issues and syntactic or word order issues. They accept that semantically, students regularly do not consider multi-word verbs as a lexical unit that conveys unique meaning. This will be more clear when there is no presence of PVs in the student's first language. Even though teaching phrasal verbs is problematic, it is required as they are of high relevance for ESL/ EFL learners because knowledge of them is often equated with language proficiency and fluency (Zarifi \& Mukundan, 2019).
Considering PVs are vital and hard to learn but it is important to be mastered by English learners, this study attempted to make a list of PVs in the tourism context to know which phrasal verbs must be given priority considering a large number of phrasal verbs available. One of the ways to do this is based on frequency criteria (Garnier \& Schmitt, 2014; Liu \& Myers, 2018) and corpus linguistics is one of the methods that use frequency data to identify and grouping of multiword units (Gardner \& Davies, 2007).

A corpus is data derived from a large electronic text collection so it has the benefits of being readable from the machine, and allows dictionarymaker to extract all authentic and typical examples of lexical item usage from within seconds and easily provide collocation frequency and quantification information (Mcenery $\&$ Xiao, 2004). Corpus linguistics has recently been used in ELT activities. At least there are three major advantages if the corpus is applied in ELT such as improving language descriptions and features that can inform the language to the teacher; providing the teacher with corpora and a tool to analyze them; and putting them in the learner's hands immediately (Cobb \& Boulton, 2015).

With these three main benefits, it shows that the corpus provides significant impact in ELT even though there is still a lot of work to be done such as the gap between research and practice (Sinclair,2011), the lack of progress on corpus research in ELT practice and the lack of familiarity with the corpus or 
concordance between teachers and students (Mukherjee, 2004) and whether the results of the analysis corpus can be fully implemented in teaching as it must be modified and adjusted to meet the needs of teaching and learning (Oktavianti \& Sarage, 2021).

With regards to ELT, there are a few numbers of studies that underline how corpus linguistics has a solid association with teaching vocabulary. Valipouri \& Nassaji (2013) used corpus linguistics to develop a list of academic words used frequently in chemistry research articles and to compare the word list with the distribution of high-frequency words in Coxhead's (2000). Although the corpus included 4 million words, the study was focused on one basic word. Similarly, another study conducted by Ashkan \& Hassan (2016) used corpus in classroom teaching to test the implementation of corpus-based learning toward EFL students' vocabulary retention but the test only consists of 40 multiple-choice vocabulary items that are not specifically stated whether the selected word is multi-word or one basic word, although the method of obtaining the data is based on the frequency of words that appear in English books in high school (preuniversity level).

Some previous studies have been conducted in connection with a phrasal verb and the utilization of corpus. Liu \& Myers (2018), for example, extend the study of Garnier \& Schmitt (2014) but include the cross-register analysis by studying and comparing the meaning distributions of the 150 most common
PVs in spoken English and academic writing. The result showed that there are significant cross-register differences among most of the 150 most common PVs and this suggests that an instructional approach to PV should prioritize different meanings of PV depending on the type of register. Other studies such as that conducted by Schmitt (2016) attempted to understand L2 students' knowledge of polysemous phrasal verbs that are very common in English, and what factors influence knowledge of phrasal verbs. The result showed that only $40 \%$ of the sense phrases of phrasal verb meanings are known. Semantic opacity factors, previous L2 instruction, immersion in an L2 environment, and years of BA study did not affect knowledge and their relationship was not found between knowledge of phrasal verbs and hours spent listening to music and watching movies.

The comparison of L2 knowledge in receptive and productive related to 100 polysemous phrasal verbs was measured by Sonbul, et. all. (2020). Their study examines factors that might determine EFL learners' receptive and productive knowledge of polysemous phrasal verbs such as (1) raw phrasal verb frequency, (2) sense-based phrasal verb frequency, (3) entrenchment or individual word frequency, (4) sense opacity, (5) L2 estimated proficiency, and (6) the amount and type of L2 exposure. The result of the study showed that the strongest predictor was corpusderived frequency.

Alangari et. all (2019) have used a novel methodology (Quirkian 
approach) to identify the extent to which PVs are used in academic writing and compare to other categories of verbs taken from nine English journals that were selected. The most frequent 100 verbs were identified. In contrast, the results showed that PVs form a large part of the verbs identified by experts in writing. This violates the existing opinion that phrasal verbs have no place in formal academic writing.

The aforementioned studies indicated that corpus linguistics was very favorable in teaching and learning English. However, the use of corpus in phrasal-verb analysis has been limited and only conducted by some researchers, for example, Gardner \& Davies (2007), Garnier \& Schmitt (2014), Liu \& Myers (2018), Siyanova \& Schmitt (2007).

Similarly, this study attempted to use a corpus-based approach to create a list of PVs in the context of English for Tour and Travel Corpus (ETTC). Although the method is quite similar to Laosrirattanachai \& Ruangjaroon's study (2021), this study proposes ETTC corpus as a newly compiled corpus and the focus of the study is on the PVs rather than a single word. A small corpus (ETTC) was created based on articles related to English for tour and travel so that the occurrence of the phrasal verbs can be known. In particular, this study attempted to answer these two questions:

1.) What Phrasal Verbs are found in the ETTC?

2.) How are the students familiar with the phrasal verbs found in the ETTC?

\section{Research Method}

This research used the corpus linguistics method (Stefanowitsch, 2020) as it compiles a small corpus named ETTC and analyses the PVs found. This research collected 100 articles related to Tour and Travel from several websites as follows:

\section{Table1. The website address and number of articles in ETTC}

\begin{tabular}{|c|c|}
\hline Website address & $\begin{array}{c}\text { Num } \\
\text { ber of } \\
\text { articl } \\
\text { es } \\
\end{array}$ \\
\hline www.lonelyplanet.com & 20 \\
\hline $\begin{array}{l}\text { https://indietravelpodcast. } \\
\text { com }\end{array}$ & 6 \\
\hline $\begin{array}{c}\text { https://www.thetravelmag } \\
\text { azine.net }\end{array}$ & 7 \\
\hline $\begin{array}{c}\text { http://www.travelandtour } \\
\text { world.com }\end{array}$ & 32 \\
\hline $\begin{array}{c}\text { https://www.traveldailyne } \\
\text { ws.com }\end{array}$ & 15 \\
\hline $\begin{array}{c}\text { https://www.travelweekly. } \\
\text { com }\end{array}$ & 4 \\
\hline $\begin{array}{c}\text { https://traveltips.usatoday. } \\
\text { com }\end{array}$ & 16 \\
\hline Total & 100 \\
\hline
\end{tabular}

The corpus data created did not include commercial or advertising information to reflect the use of actual texts in the context of tours and travel. When selecting articles, the length of the article was considered to earn a larger number of tokens. The text excluded from the advertisement was saved in txt format so that it can be analyzed with AntConc software and a corpus can be produced.

Data analysis using Antconc software was carried out to find out language 
features such as frequency and part of speech then corpus annotation using Claws 7 Tagset was carried out to find PVs in the (POS) tags. AntConc is software-free, uncomplicated, and easy to use. It includes sophisticated concordancers, a word, and keyword frequency generator, cluster and lexical bundle analysis tools, and a word distribution, and the Claws program is based entirely on probability statistics, which ensures a level of accuracy of 96-97 percent (Kang \& Yu, 2011). In the annotation process, the RP tagset is focused as it indicates prep. adverb, particle (e.g about, in) as an element to construct PVs and the possibility of verbs Tagset which are followed by particles are VVI (infinitive, e.g. to give... It will work...), VVG (-ing participle of the lexical verb (e.g. giving, working), and VV0 (base form of the lexical verb, e.g. give, work).

The PVs in the corpus were classified after the annotation process. This process was performed by selecting the VVI/VVG/VV0 results and then by selecting an RP annotation. This process was carried out by examining each combination of these tags as separable and inseparable PVs are available and as shown in the following example:

1. Keep_VV0 an_AT1 eye_NN1 out_RP forHysteria_NN1 Mas_JJ

2. Bermuda_NP1 Heroes_NN2 Weekendfestivities_NN2 kick_VVO off_RP on_II a_AT1

3. cascading_VVG through_II your_APPGE veins_NN2,,

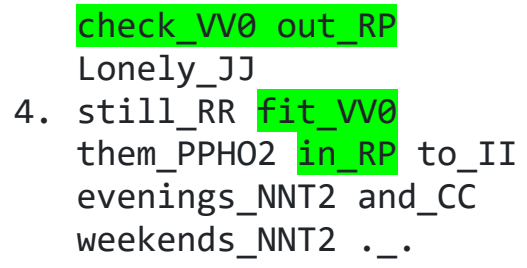

To find out whether PVs found were familiar or not for Hospitality students, the sample was chosen from fourth-semester students majoring in Hospitality at STIPARY Tourism Academy. The students were chosen since they had already studied English for at least 8 years and would be expected to recognize the PVs found. The fourth-semester students were divided into three classes consisting of 35 students from A-class, 31 students from B class, and 32 students from $\mathrm{C}$ class so the total sample was 98 students. Two questionnaires were administered to each student. The first questionnaire was used to determine whether or not the students were familiar with the PVs discovered. The second questionnaire was given to know whether the students could discern the difference between PVs and prepositional verbs.

An impromptu speaking test was the next procedure. To know their ability in using PVs, 20 students were chosen at random from the sample who completed questionnaires 1 and 2 and instructed to produce three sentences directly using different PVs discovered in the corpus.

\section{Results}

Phrasal Verbs found in the ETTC and its familiarity for students 
Based on the annotation results using Claws 7, 172 PVs were found from ETTC(see Appendix 1). All the phrasal verbs were included in Questionnaire 1 and it was distributed to all students to confirm whether they know the meaning of all phrasal verbs found in ETTC or not. After the questionnaire was distributed, 59 students returned the questionnaire and the results can be seen in Appendix 2. Based on the data obtained, it can be seen that there are $10 \mathrm{PVs}$ that are most familiar to students. It can be seen in the following table:

Table 2. The Percentage of the respondents who really knows the meaning of PVs

\begin{tabular}{|r|l|l|}
\hline No & \multicolumn{1}{|c|}{ PVs } & Percentage \\
\hline 1 & Check-in & $98,30 \%$ \\
\hline 2 & Check out & $89,80 \%$ \\
\hline 3 & Come back & $88,1 \%$ \\
\hline 4 & Wake up & $86,40 \%$ \\
\hline 5 & Follow up & $83,10 \%$ \\
\hline 6 & Stand up & $83,10 \%$ \\
\hline 7 & go back & $79,70 \%$ \\
\hline 8 & take off & $79,70 \%$ \\
\hline 9 & come in & $78 \%$ \\
\hline 10 & set up & $76,30 \%$ \\
\hline
\end{tabular}

From the table above, $98,30 \%$ of the total respondents know the meaning of "check-in" and $89,80 \%$ of them know the meaning of "check out". This indicates that "check-in" and "check out" are familiar PVs to them, considering that these two PVs are often found in the hospitality context or close to the student's educational background. However, based on the data, some students know the meaning of PVs but they cannot differentiate between PVs and prepositional verbs. This can be seen from the total students who know the meaning of "check-in" at $98.30 \%$ (see table 2) but the total percentage toward this as PVs category is only $87,90 \%$ as can be seen in table 3 .

In addition, the list of existing phrasal verbs was not chosen entirely by the students. It can be seen from no phrasal verb chosen until it reaches a percentage of $100 \%$. It means, not all of them know what a phrasal verb is. From the results of the questionnaire, it can be seen that the top $10 \mathrm{PVs}$ in table 2 are phrasal verbs that are the most familiar PVs to the majority of students. From the table, it can be seen that the most familiar PVs for the majority of students are check-in followed by check-out. This is not much different from the results in table 3 which shows the percentage of the students in distinguishing PVs and prepositional verbs.

\section{Table 3. The Percentage of the respondents choosing PVs in ETTC correctly}

\begin{tabular}{|c|c|c|}
\hline No & PVs & Percentage \\
\hline 1 & check out & $94,80 \%$ \\
\hline 2 & check-in & $87,90 \%$ \\
\hline 3 & come in & $86,20 \%$ \\
\hline 4 & get on & $82,2 \%$ \\
\hline 5 & get out & $81 \%$ \\
\hline 6 & go on & $81 \%$ \\
\hline 7 & keep out & $81 \%$ \\
\hline 8 & follow up & $79,30 \%$ \\
\hline 9 & fill up & $77,6 \%$ \\
\hline 10 & find out & $75,9 \%$ \\
\hline
\end{tabular}


Based on the above analysis, it raises a hypothesis for further research that knowing the meaning of PVs is not necessarily in line with understanding what PVs are.

Table 3 above also explained whether the students can differentiate PVs and prepositional verbs. From 98 students as a total sample, only 58 students gave responses toward questionnaire 2 containing about 100 Phrases (PVs and prepositional verb) as can be seen in see in appendix 4. The respond of the students to the questionnaire can also be seen in Appendix 3.

Based on the results of the students' responses, it can be seen that many students cannot distinguish between PVs and prepositional verbs. It can be seen that of the 58 students who returned the questionnaire 2 considered VPs as a prepositional verb as can be seen in the following table:

Table 4. The Percentage of misperception of the respondents toward Prepositional Verb and PVs in ETTC

\begin{tabular}{|l|l|l|}
\hline \multicolumn{1}{|c|}{ o } & \multicolumn{1}{|c|}{ PV } & \multicolumn{1}{c|}{$\begin{array}{c}\text { Percentag } \\
\text { e }\end{array}$} \\
\hline 1 & $\begin{array}{l}\text { ride } \\
\text { from }\end{array}$ & $44,80 \%$ \\
\hline 2 & $\begin{array}{l}\text { learn } \\
\text { before }\end{array}$ & $24,10 \%$ \\
\hline 3 & open to & $44,80 \%$ \\
\hline 4 & $\begin{array}{l}\text { swim } \\
\text { from }\end{array}$ & $31 \%$ \\
\hline 5 & place on & $48,30 \%$ \\
\hline 6 & $\begin{array}{l}\text { choose } \\
\text { from }\end{array}$ & $22,40 \%$ \\
\hline 7 & $\begin{array}{l}\text { dip } \\
\text { before }\end{array}$ & $15,50 \%$ \\
\hline
\end{tabular}

\begin{tabular}{|l|l|l|}
8 & $\begin{array}{l}\text { close } \\
\text { by }\end{array}$ & $36,20 \%$ \\
\hline 9 & turn to & $50 \%$ \\
\hline 10 & $\begin{array}{l}\text { continu } \\
\text { e along }\end{array}$ & $17,20 \%$ \\
\hline 11 & head to & $44,80 \%$ \\
\hline 12 & $\begin{array}{l}\text { contact } \\
\text { with }\end{array}$ & $24,10 \%$ \\
\hline 13 & $\begin{array}{l}\text { want } \\
\text { with }\end{array}$ & $22,4 \%$ \\
\hline 14 & $\begin{array}{l}\text { focus } \\
\text { around }\end{array}$ & $22,4 \%$ \\
\hline 15 & $\begin{array}{l}\text { visit } \\
\text { during }\end{array}$ & $24,10 \%$ \\
\hline 16 & sit next & $27,60 \%$ \\
\hline 17 & $\begin{array}{l}\text { stroll } \\
\text { through }\end{array}$ & $35,50 \%$ \\
\hline 18 & ask at & $39,70 \%$ \\
\hline 19 & visit to & $53,40 \%$ \\
\hline 20 & $\begin{array}{l}\text { stray } \\
\text { beyond }\end{array}$ & $22,40 \%$ \\
\hline & &
\end{tabular}

The table above shows 20 top prepositional verbs which were considered as PVs by the students. The prepositional verbs "visit to" and "turn to" were considered as phrasal verbs by the majority of students with the total percentage of $53 \%$ and $50 \%$ respectively. Therefore, what phrasal verb is and how to use them should be paid more attention in teaching English particularly for Hospitality students.

\section{The students' ability in using phrasal verbs found in the ETTC}

Besides investigating the students' familiarity with the PVs found in ETTC, it is critical to present a description related to students' ability in using PVs. A speaking test is given 
to determine whether or not the students can employ PVs. This is conducted since the students are Hospitality majors who tend to use verbal communication in the workplace in the hospitality industry. Twenty students were chosen from the 58 who completed the questionnaire and asked to make three complete sentences using three randomly selected phrasal verbs in ETTC. Of the 20 students, all of them could not generate 3 sentences using the PVs correctly, even 16 students were unable to make one or two sentences of the three PVs provided. For example, the results of the speaking test with students with the initials NR.

I : Okay, NR, this is the first PV to be used in a sentence, check-in,you only have 15 seconds to think. NR: The guest will be check-in at 12 p.m.

T: Okay, the next is come back

$S$ : I can not

Based on the speaking test result above, although the students could create the sentence using PV "checkin", but the sentence is grammatically incorrect. Before the word "checkin", it should not be added with the auxiliary verb 'be'. This shows that the use of PVs in the correct sentence should be a concern even though the student is familiar with and able to make sentences with the PV.

The results of the speaking test above also indicate that even though the respondents are students at a university and have studied English for a long time, PVs are still a problem for them in using English, this is evident from the student NR who cannot make a sentence using PV 'come back'.

This analysis is supported by the results of the students' responses with the initial "M" in the test as follows:

\section{I: Ok next go on.}

M: We go on door prizes in some competitions

Based on the online dictionary (Merriam-Webster., n.d.), the word "go on" has several meanings such as (1) to continue on or as if on a journey, to keep on, proceed (2): to take place (3): to talk especially in an effusive manner and it is used as an intransitive verb which does not require an object as in the example life goes on. However, student $\mathrm{M}$ makes sentences using PVs "go on" without understanding the meaning of the PVs so that the sentence he made was not semantically appropriate. Another example is the result of a speaking test with a student with the initial ' $\mathrm{K}$ ' who was asked to make a sentence using the PVs 'stop in'.

\section{I: Ok, Next, Stop in... \\ $K$ : I will stop in to love you}

Based on the results of the speaking test above, the student does not understand the meaning of "stop in", although the phrase may be very familiar to him. according to the Merriam-Webster dictionary (Merriam-Webster., n.d.), the phrase "stop in" has the meaning (1): to visit someone briefly or (2): to stay at home. 
The sentence I will stop in to love you made by the student indicates that the phrase "stop in" is interpreted as a phrase that has the same meaning as the main verb "stop" which can be used in the context of a similar sentence as in the sentence "I stop loving you".

Although this is a preliminary study in which researchers did not employ a more systematic data collection approach, the relationship between the students' familiarity and ability associated with PVs in ETTC has to be investigated further in future studies and a bigger corpus can be created in this study a small corpus has been created as the data used is still very limited in this study. The findings of this study are also relevant in terms of validating prior studies, such as Garnier \& Schmitt (2016), which concluded that phrasal verbs are a problematic part of English vocabulary for many learners and demand more concern. The next research can focus on not only making the learners aware of whether a phrase can be classified as a phrasal verb or not but also making them understand how to use them accurately.

\section{Conclusion}

Based on data analysis, it can be concluded that there are $172 \mathrm{PVs}$ found in the ETTC (English for Tour and Travel Corpus) where all students are not $100 \%$ know their meaning. Based on the analysis data, the most familiar PVs for students are "checkin" and "check out" considering those two PVs are frequently used in the context of hospitality and it is suitable with the students' educational background. In addition, not all students who are certain of the meaning of PVs are aware that the phrase is PVs as many prepositional verbs are considered PVs by them. The last is that the familiarity with PVs does not guarantee that the students can make sentences using PVs correctly.

Of course, further research is necessary to confirm the reasons that lead to students being unable to employ PVs appropriately in speaking. Why students who have been learning English for a long time are still unable to discern between PVs and prepositional verbs becomes a huge question that has to be researched further in terms of teaching and learning English. In addition, it is critical to conduct a further study regarding how PV is properly taught to students so that it can be employed in speaking.

\section{References}

Alangari, M., Jaworska, S., \& Laws, J. (2019). Who's afraid of phrasal verbs? The use of phrasal verbs in expert academic writing in the discipline of linguistics. Journal of English for Academic Purposes, 100814. https://doi.org/10.1016/j.jeap.20 19.100814

Alqahtani, M. (2015). The importance of vocabulary in language learning and how to be taught. International Journal of Teaching and Education, III(3), 21-34. https://doi.org/10.20472/TE.20 15.3.3.002 
Ashkan, L., \& Hassan Seyyedrezaei, S. (2016). The Effect of CorpusBased Language Teaching on Iranian EFL Learners' Vocabulary Learning and Retention. International Journal of English Linguistics, 6(4), 190-196.

https://doi.org/10.5539/ijel.v6n4 p190

Blau, E. K., Gonzales, J. B., \& Green J. M. (1983). Helping students sort out phrasal verbs. In H. F. John (Ed.), Selected articles from the TESOL newsletter, 1986-1983. Washington, DC

Bradwell, S. (2006). Helping Upper Intermediate Learners Come to Grips with Multi-words Verbs. Retrieved August 6th, 2021, from

https://www.developingteacher s.com/articles_tchtraining/voca b1_sandra.htm

Cobb, T. \& Boulton, A. (2015). Classroom applications of corpus analysis. In D. Biber \& R. Reppen (eds), Cambridge Handbook of English Corpus Linguistics. Cambridge: Cambridge University Press, p. 478-497.

DOI: 10.1017/CBO9781139764377. 027

Coxhead, A. (2000). A New Academic Word List. TESOL Quarterly, 34(2), 213-238.

Frank, M. (2002). Modern English. New York: Prentice Hall, Inc.

Gardner, D., \& Davies, M. (2007). Pointing out frequent phrasal verbs: A corpus-based analysis. TESOL Quarterly, 41, 339-359.

Garnier, M., \& Schmitt, N. (2014). The PHaVE List : A pedagogical list of phrasal verbs and their most frequent meaning senses. Language Teaching Research, 1(2007). https://doi.org/10.1177/1362168 814559798

Garnier, M., \& Schmitt, N. (2016). Picking up polysemous phrasal verbs : How many do learners know and what facilitates this knowledge? System, 59, 29-44. https://doi.org/10.1016/j.system. 2016.04.004

Kang, N., \& Yu, Q. (2011). Corpusbased stylistic analysis of tourism English. Journal of Language Teaching and Research, 2(1), 129-136. https://doi.org/10.4304/jltr.2.1.1 29-136

Laosrirattanachai, P., \& Ruangjaroon, S. (2021). Corpus-based Creation of Tourism, Hotel, and Airline Business Word Lists. LEARN Journal: Language Education and Acquisition Research Network, 14(1).

Liu, D., \& Myers, D. (2018). The most-common phrasal verbs with their key meanings for spoken and academic written English: A corpus analysis. Language Teaching Research, 1 -22 .

https://doi.org/10.1177/1362168 818798384

Merriam-Webster. (n.d.). Stop in. In Merriam-Webster.com dictionary. Retrieved August 5, 2021, from https://www.merriamwebster.com/dictionary/stop $\% 2$ Oin

Merriam-Webster. (n.d.). Goon. In Merriam-Webster.com 
dictionary. Retrieved August 5, 2021, from https://www.merriamwebster.com/dictionary/goon McCarthy, M., \& O’Dell, F. (2004). English phrasal verbs in use. Intermediate Level. Cambridge: Cambridge University Press.

Mcenery, T., \& Xiao, R. (2004). What Corpora Can Offer in Language Teaching and Learning, (2007), 364-380. Retrieved from https://www.lancaster.ac.uk/fas s/projects/corpus/ZJU/xpapers/ McEnery Xiao teaching.PDF

Mukherjee, J. (2004). Bridging the gap between applied corpus linguistics and the reality of English language teaching in Germany. In Applied Corpus Linguistics (pp. 239-250). Brill.

Oktavianti, I. N., \& Sarage, J. (2021). Collocates of'great'and'good'in the Corpus of Contemporary American English and Indonesian EFL textbooks. Studies in English Language, $8(2), 457-478$. Retrieved from http://erepository.unsyiah.ac.id/SiELE/ article/view/18594

Schmitt, N. (2016). Picking up polysemous phrasal verbs: How many do learners know and what facilitates this knowledge? System, 59, 29-44. https://doi.org/10.1016/j.system. 2016.04.004

Sinclair, J. (2011). Corpus Research Applications in Second Language Teaching Ute $\mathrm{R}$ omer, 205-225. https://doi.org/10.1017/S02671 90511000055
Siyanova, A., \& Schmitt, N. (2007). Native and nonnative use of multi-word vs. one-word verbs. IRAL-International Review of Applied Linguistics in Language Teaching, 45, 119$139 . \quad$ http://dx.doi. org/10.1515/IRAL.2007.005

Sonbul, S., El-dakhs, D. A. S., \& Alotaibi, H. (2020). Productive versus receptive L2 knowledge of polysemous phrasal verbs: A comparison of determining factors. System, 102361. https://doi.org/10.1016/j.system. 2020.102361

Stefanowitsch, A. (2020). Corpus linguistics: A guide to the methodology. Language Science Press.

Tanihardjo, J. (2019). Indonesian Efl Learners' Recognition and Production of Phrasal Verb. Prosiding Seminar Nasional Linguistik Dan Sastra ..., 369377. Retrieved from https://jurnal.uns.ac.id/prosidin gsemantiks/article/view/39033

Thim, S. (2012). Phrasal verbs. Berlin: De Gruyer Mouton.

Valipouri, L., \& Nassaji, H. (2013). A corpus-based study of academic vocabulary in chemistry research articles. Journal of English for Academic Purposes, 12(4), 248263.

https://doi.org/10.1016/j.jeap.20 13.07 .001

Zarifi, A, \& Mukundan, J. (2013). Phrasal verb combinations in corpus-based studies: A critical review. International Journal of Applied.Retrieved from http://www.journals.aiac.org.au/ index.php/IJALEL/article/view/ 
999

Zarifi, Abdolvahed;, \& Mukundan, J. (2019). Use of Phrasal Verbs in an ESL Learner Corpus and its
Corresponding Pedagogic

Corpus. Social Sciences \& Humanities, 27(4), 2185-2200. 


\section{Appendix 1: PVs found in ETTC}

1. agree its up there

2. asking around about

3. blend in

5. boarding down

6 . boost up

7. breaking up

8 . bring in

9. build up

10. calling out

11. carry on

12. carry out

13. Change Up

14. check in

15. check out

16. chill out

17. choose from

19. claiming back

20. clearing up

21. close by

22. come back

23. come in

24. come up

25. coming along

26. coming back

27. Continue along

28. cut up

29. dating back

30. dig in

31. Dining out

32. dish out

33. dive in

34. dress up

35 . driving around

36. drying off

37. tempt you in

38. end up

40. fill up

41. filling out

42. find out
43. fit in

44. focus around

45. fold up

46. Follow up

48. get right down

49. get around

50 . get by

51. Get down

52. get off

53. get on

54. get out

55. getting around

56. getting out

57. give back

58. go around

59. go back

60. Go on

61. go up

62. going all out

63. going back

64. going out

65. hang on

66. hanging out

67. head over

68. Heading off

69. heading out

70. hike up

72. invest in

73. jump over

75 . keep out

76. keep up with

77. kick off

78. leading down

79. learn about

80. let off

81. List out

82. living in

83. loading up

84. Look around 
85. Look out for

86. looking back

87. looking down

88. Looking out into

89. losing out

92. make up

95. mingle along

96. miss out

98. moving about

99. open in late

100. opening up

101. pick up

103. plunge in

104. pop over

105. pop up

106. pull out

107. put up

108. Reach out

109. realise along

110. ride back down

111. rise up

113. roll out

114. Scrambling up

115. searching out

116. send me off

117. Serving up

118. set off

119 . set out

120. set up

121. settle in

122. Shake up

123. shoot up

124. show off

125. show up

126. shut down

127. sign up

128. sit back
129. sit down

130. skip through

131. slide down

133. speed up

135. spread out

136. stand in

137. stand up

138. Step back into

139. step up

141. stop in

144. summon up

145. survive on

146. swim around

147. swim by

148. Swim in

149. take up

150. take children out

151. take off

152. take on

153. take over from

154. taking out

155. throw down

156. Tie up

157. top up

158. travel along

159. try out

161. wake up

162. walk along

163. walk back

164. walk down

165. walk out

167. warm up

168. watch out

169. win over

170. wipe out

171. youre better off

172. Youre up for 
Appendix 2: The number of the respondents who really knows the meaning of PVs in ETTC 


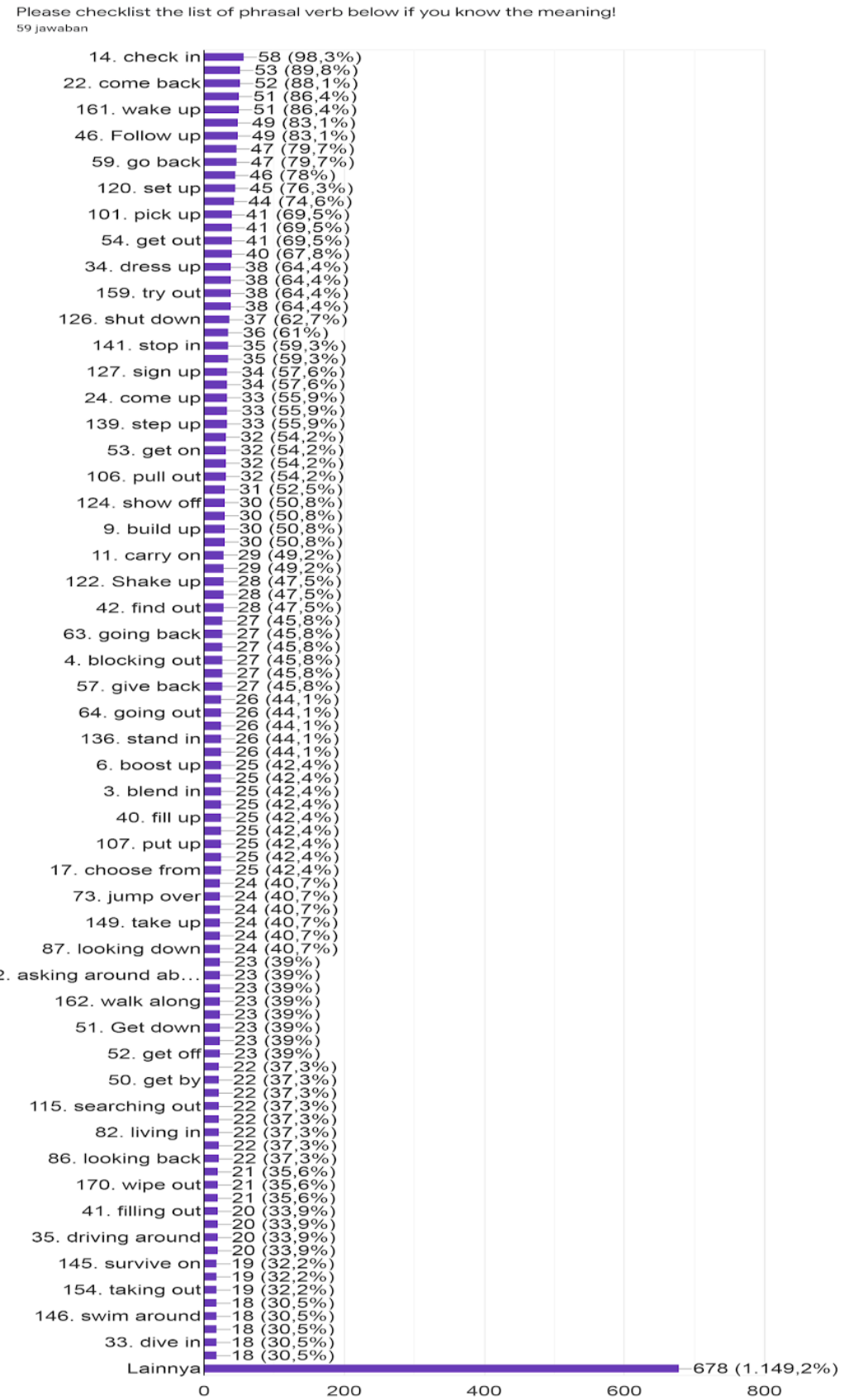




\section{Appendix 3: The students responses on differentiating PVs and VP}

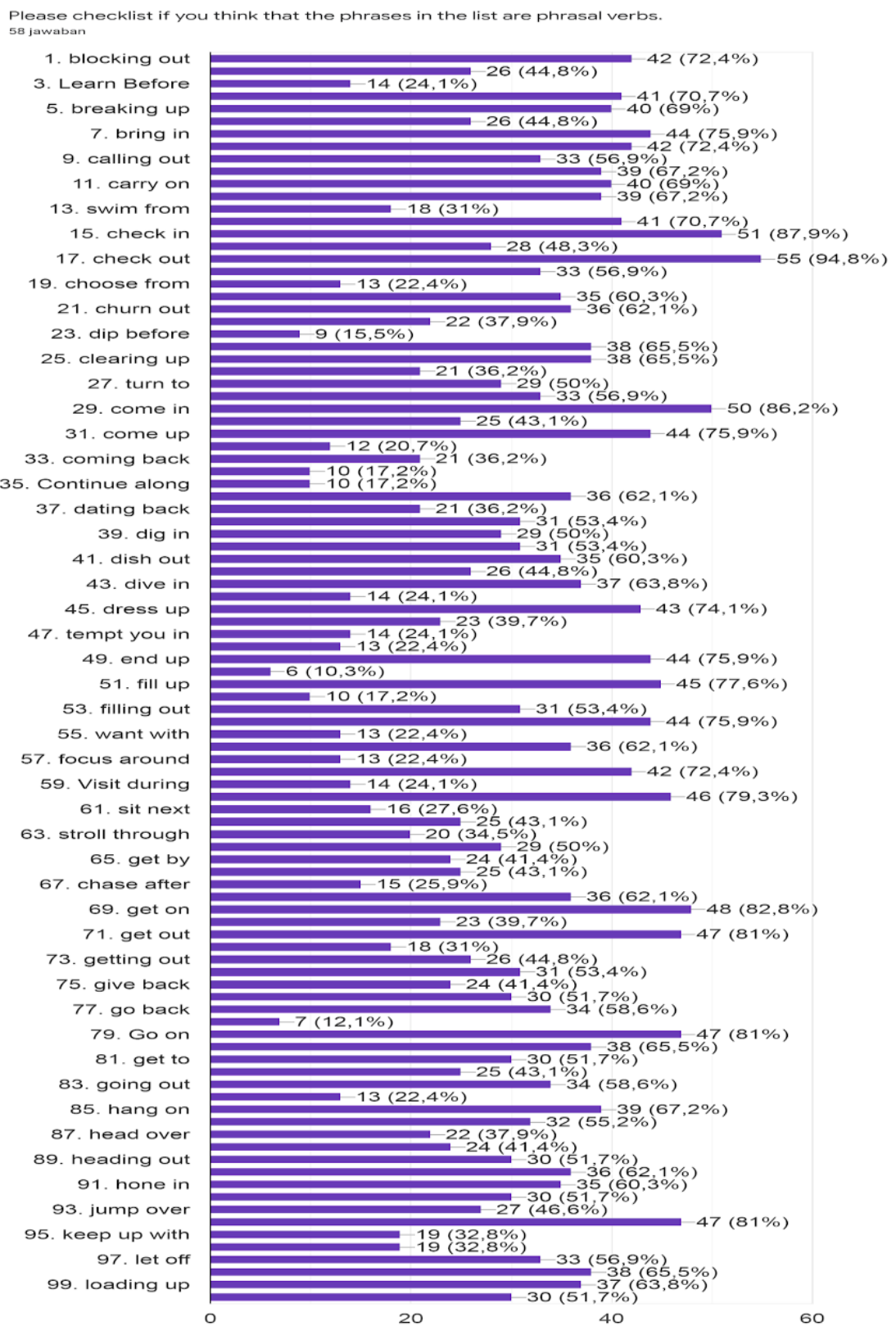




\section{Appendix 4: The Qestionnaire 2 ( Differentiating PVs and VP)}

Please checklist if you think that the phrases in the list are phrasal verbs.

1. blocking out

2. Ride from

3. Learn Before

4. boost up

5. breaking up

6. open to

7. bring in

8. build up

9. calling out

10. check on

11. carry on

12. carry out

13. swim from

14. Change Up

15. check in

16. place on

17. check out

18. chill out

19. choose from

20. see in

21. churn out

22. claiming back

23. dip before

24. click on

25. clearing up

26. close by

27. turn to

28. come back

29. come in

30. want in

31. come up

32. coming along

33. coming back

34. free from
35. Continue along

36. cut up

37. dating back

38. go with

39. dig in

40. Dining out

41. dish out

42. head to

43. dive in

44. contact with

45. dress up

46. drying off

47. tempt you in

48. finish with

49. end up

50. Evolving over

51. fill up

52. differ from

53. filling out

54. find out

55. want with

56. fit in

57. focus around

58. fold up

59. Visit during

60. Follow up

61. sit next

62. get right down

63. stroll through

64. get around

65 . get by

66. Get down

67. chase after

68. get off
69. get on

70. ask at

71. get out

72. getting around

73. getting out

74. visit to

75. give back

76. go around

77. go back

78. remain under

79. Go on

80. go up

81. get to

82. going back

83. going out

84. Stray beyond

85. hang on

86. hanging out

87. head over

88. Heading off

89. heading out

90. hike up

91. hone in

92. invest in

93. jump over

94. keep out

95. keep up with

96. leading down

97. let off

98. List out

99. loading up

100. Look around

\section{Answerkey:}

Number of PVs in the Qestionnaire :

$1,4,5,7,8,9,10,11,12,14,15,17,18,20,21,22,24,25,28,29,30,31,32,33,34,36,37,38,39$ 
,40,41,43,45,46,47,48,49,50,51,52,53,54,56,58,60,62,64,65,66,67,68,69,71,72,73, $75,76,77,78,79,80,81,82,83,85,86,87,88,89,90,91,92,93,94,95,96,97,98,99,100$

Number of VP in the Qestionnaire :2,3, 6,13,16,19,23, 26, 27, 35, 42,44, 55, 57, $59,61,63,70,74,84$ 